\title{
Uji Aktivitas Antioksidan Infusa Biji Kopi Arabika (Coffea arabica L.): Pengukuran Kadar Malondialdehid (MDA) pada Tikus Wistar (Rattus novergicus) Hiperurisemia
}

\author{
Anna Maria Dewajanti ${ }^{1}$, Erma Mexcorry Sumbayak ${ }^{2}$, Maria Andriana Neno ${ }^{3}$ \\ ${ }^{1}$ Staf Pengajar Bagian Biokimia, Fakultas Kedokteran Universitas Kristen Krida Wacana \\ ${ }^{2}$ Staf Pengajar Bagian Histologi, Fakultas Kedokteran Universitas Kristen Krida Wacana \\ ${ }^{3}$ Mahasiswa Fakultas Kedokteran Universitas Kristen Krida Wacana \\ Alamat Korespondensi : anna.dewajanthi@ukrida.ac.id
}

\begin{abstract}
Abstrak
Pada keadaan hiperurisemia terjadi peningkatan jumlah radikal bebas. Salah satu indikator peningkatan radikal bebas pada manusia adalah meningkatnya kadar malondialdehid (MDA). Tujuan penelitian ini untuk menguji aktivitas infusa biji kopi arabika sebagai antioksidan dengan cara mengukur kadar MDA darah. Tikus dibagi dalam 5 kelompok kontrol (tikus normal), tikus hiperurisemia tanpa perlakuan dengan kopi, serta tiga kelompok tikus hiperurisemia yang diberi perlakuan pemberian kopi dosis yang berbeda $(0,5 \mathrm{mg} / 200 \mathrm{~g}$ berat badan (BB); 0,25 mg/200g BB; dan $0,15 \mathrm{mg} / 200 \mathrm{~g} \mathrm{BB})$. Setiap kelompok terdiri dari 5 ekor tikus yang diambil darahnya pada jam ke-6 dan jam ke-21. Uji posthoc menunjukkan perbedaan yang signifikan dengan nilai $\mathrm{p}<0,05$ pada jam ke-21 setelah pemberian infusa kopi arabika. Penurunan kadar MDA paling efektif pada kelompok $\mathrm{K} 3$, yaitu tikus hiperurisemia dengan pemberian dosis kopi $0,5 \mathrm{mg} / 200 \mathrm{~g}$ BB. Kesimpulannya adalah infusa kopi arabika memiliki aktivitas sebagai antioksidan, dibuktikan dengan adanya penurunan kadar MDA tikus hiperurisemia pada penelitian ini.
\end{abstract}

Kata kunci: hiperurisemia, kopi arabika, malondialdehid, tikus wistar.

\section{Antioxidative Effect of Arabica (Coffea arabica L.) Coffee Beans infusion on Hiperuricemic Rats Wistar (Rattus novergicus) : Measurement of Plasma Malondialdehyde (MDA) Level}

\begin{abstract}
Hyperuricemia has been associated with an increase number of free radicals as indicated by higher levels of Malondialdehid (MDA). In this study, possible antioxidative effect of coffee infusion was investigated, by measuring MDA plasma levels in experimentally induced hyperuricemia rats. Twenty-five wistar rats were divided into 5 groups, two of which were control. Group-1 was control, consisting of healthy rats, whereas group-2 was hyperuricemic control. Hyperuricemic was induced by oral administration of oxonic acid potassium salt of $2 \mathrm{ml} / 200 \mathrm{~g} \mathrm{bw}$. Hyperuricemia was induced in all rats in group 3 to 5, thereafter were treated orally with $2 \mathrm{ml}$ of coffee infusion. Group-3, 4 and 5 were treated with coffee dose of $0.5 \mathrm{mg} / 200 \mathrm{~g} \mathrm{bw}), 0.25 \mathrm{mg} / 200 \mathrm{~g} \mathrm{bw}$ ), and $0.15 / 200 \mathrm{~g} \mathrm{bw}$, respectively. MDA levels in blood plasma was determined spectrophotometrically at $532 \mathrm{~nm}$ at 6 th and 21 st hour after receiving coffee infusion. A posthoc test showed a very significant difference ( $p$ $<0.05)$ at the 21 st hour after coffee administration. The reduction in MDA levels was most effective in the K3 group, hyperuricemic rats with a coffee dose $0.5 \mathrm{mg} / 200 \mathrm{~g} \mathrm{bw}$. The conclusion is that the decrease in MDA levels in hyperuricemic rats in this study proved that Arabica coffee infusions have antioxidant activity.
\end{abstract}

Keywords: arabica coffee, hyperurisemia, Malondialdehyde, wistar rats 


\section{Pendahuluan}

Hiperurisemia adalah suatu kondisi di mana kadar asam urat dalam tubuh lebih dari nilai normal. Nilai normal asam urat manusia $2,4-5$, $7 \mathrm{mg} / \mathrm{dL}$ pada wanita dan $3,5-7,0 \mathrm{mg} / \mathrm{dL}$ pada pria. ${ }^{1,2}$ Jika kadar asam urat berlebihan di dalam darah maka akan menimbulkan penumpukan kristal monosodium urat. ${ }^{3}$ Penumpukan kristal umumnya pada jaringan sekitar sendi, sehingga menimbulkan rasa nyeri di daerah tersebut, ${ }^{4}$ yang dikenal dengan penyakit gout (asam urat). ${ }^{5}$ Penumpukan asam urat dapat terjadi di ginjal dan membentuk batu ginjal yang akan membentuk sumbatan pada ureter. ${ }^{5}$

Hiperurisemia dapat disebabkan oleh terganggunya pengeluaran asam urat dari dalam tubuh. ${ }^{3,6}$ Asam urat sangat berkaitan erat dengan pola makan yang tidak seimbang dimana jumlah asupan purin sangat tinggi. ${ }^{2}$ Sumber makanan tinggi purin terdapat dalam produk hewani seperti hati ayam, hati sapi, ginjal sapi, otak, daging, dan unggas. ${ }^{7}$

Diet tinggi purin dapat menyebabkan tingginya kadar asam urat yang akan mengaktivasi enzim xanthin aksidase dua puluh kali lipat dari keadaan normal. Hal ini dapat menimbulkan peningkatan radikal bebas dalam tubuh yang akan menyebabkan kerusakan membran sel seperti hepar dan ginjal. ${ }^{8}$ Sebagai akibatnya rantai poly-unsaturated fatty acid (PUFA) yang semula panjang, akan terputus menjadi senyawa sederhana seperti hidrokarbon (pentana, etana) dan aldehid seperti malondialdehid (MDA). ${ }^{9}$

Dalam kehidupan sehari-hari, penderita asam urat atau gout seringkali menggunakan allopurinol sebagai obat penurun kadar asam urat dengan mekanisme kerja sebagai inhibitor xantin oksidase karena memiliki struktur mirip xantin yang merupakan substrat xantin oksidase. ${ }^{10,11}$ Allopurinol memiliki efek samping seperti mual, diare, hingga kulit kemerahan disertai gatal sehingga perlu dicari senyawa bioaktif suatu tanaman sebagai inhibitor alami xantin oksidase untuk dijadikan alternatif pengobatan yang aman untuk dikonsumsi. ${ }^{12}$

Salah satu efek dari kopi yang masih menjadi kontroversi adalah efek terhadap kadar asam urat. Beberapa penelitian menyimpulkan kandungan senyawa polifenol di dalam kopi diantaranya chlorogenic acid sekitar $8 \%$ pada biji kopi atau 4,5\% pada kopi sangrai. Pada kopi arabika yang disangrai konsentrasinya sekitar 1,9-2,5 g/100 g dan 4,1-7,9 g/100 g pada green kopi arabika. ${ }^{13-15}$ Senyawa chlorogenic acid mampu menghambat aktivitas enzim xantin oksidase sehingga dapat menurunkan kadar asam urat dan merupakan antiokasidan yang melindungi sel dari radikal bebas. ${ }^{13,14,16}$ Hasil studi di Jepang menunjukkan bahwa peminum lima gelas atau lebih kopi per hari memiliki kadar asam urat yang lebih rendah dibandingkan dengan peminum satu gelas atau kurang kopi per hari. ${ }^{17 .}$

Penelitian tentang pengaruh kopi instan terhadap penurunan kadar asam urat pada tikus wistar yakni diet kopi instan dosis rendah setara 3 cangkir kopi $(0,39 \mathrm{mg} / 3 \mathrm{~mL})$, diet kopi instan dosis sedang setara 6 cangkir kopi $(0,78 \mathrm{mg} /$ $3 \mathrm{~mL}$ ) dan diet kopi instan dosis tinggi setara 10 cangkir kopi $(1,3 \mathrm{mg} / 3 \mathrm{~mL})$ selama 4 minggu (28 hari) ${ }^{15}$ Pada uji analisis terdapat perbedaan yang bermakna kadar asam urat antara kelompok kontrol dan kelompok perlakuan, terjadi penurunan kadar asam urat dengan pemberian kopi instant pada tikus wistar hiperurisemia. ${ }^{15}$

Dengan adanya pengaruh kopi terhadap penurunan kadar asam urat pada tikus hiperurisemia diharapkan akan menurunkan senyawa-senyawa radikal yang dapat menyebabkan terjadinya peroksidasi lemak, sehingga kadar MDA di dalam darah akan menurun. ${ }^{15}$ Penelitian ini dilakukan oleh karena belum adanya penelitian sebelumnya tentang pengaruh kopi Arabica (Coffea arabica) yang diperoleh dari Bajawa, Flores-Nusa Tenggara Timur terhadap kadar MDA darah pada tikus yang hiperurisemia.

Dengan Penelitian ini diharapkan dapat menambah pengetahuan bagi masyarakat dan peneliti lain tentang efek kopi yang langsung diolah dari biji kopi, dalam menangkal/ menurunkan radikal bebas yang tinggi pada penderita hiperurisemia. Dengan turunnya radikal bebas di dalam tubuh maka mengurangi kerusakan membran sel-sel tubuh dari proses oksidasi, yang dapat menimbulkan kerusakan membran sel dari organ yang penting seperti ginjal dan hati. ${ }^{18}$

\section{Metode Penelitian}

\section{Subyek Penelitian}

Tikus percobaan jenis Rattus novergicus jantan berusia 8 minggu dan berat $200 \mathrm{~g}$ yang diperoleh dari Departemen Gizi Fakultas Kedokteran Universitas Indonesia. 


\section{Alat dan Bahan}

Darah tikus normal dan dan tikus dengan hiperurisemia, kopi dengan dosis $0,5 \mathrm{mg} / \mathrm{g} \mathrm{BB}$, $0,25 \mathrm{mg} / \mathrm{g}$ BB dan $0,15 \mathrm{mg} / \mathrm{g} \mathrm{BB}$, makanan dan minuman tikus, aquades, larutan asam Trikloroasetat (TCA) 10\%, larutan Thiobarbituratasetat (TBA), larutan Tetra Eetoksi Propane (TEP), larutan CCL4, larutan $\mathrm{NaCl}$ Fisiologis $0,9 \%$, asam asetat, eter, kalium oksonat, mikrotube $2 \mathrm{~mL}$, alat sentrifuge, spektrofotometer (Biochrom Libra S22), water bath dan timbangan analitik.

\section{Membuat Tikus Hiperurisemia}

Kalium oksonat dosis $600 \mathrm{mg} / \mathrm{kg}$ BB diberikan secara injeksi intraperitoneal sebanyak $2 \mathrm{~mL}$ untuk menginduksi hiperurisemia pada tikus. Pembuatan dosis PO $600 \mathrm{mg} / \mathrm{g}$ BB: kalium oksonat sebanyak $2 \mathrm{~g}$ dilarutkan ke dalam $40 \mathrm{~mL}$ aquades.

\section{Cara Pembuatan Infusa}

Biji kopi dihaluskan terlebih dahulu menjadi bubuk. Untuk dosis $0,5 \mathrm{mg}$ ditimbang $5 \mathrm{~g}$ bubuk kopi kemudian dilarutkan dalam 100 $\mathrm{mL}$ aquadest dan dipanaskan pada suhu $90^{\circ} \mathrm{C}$. Untuk dosis 0,25 mg ditimbang 2,5 g bubuk kopi kemudian dilarutkan dalam $100 \mathrm{~mL}$ aquadest dan dipanaskan pada suhu $90^{\circ} \mathrm{C}$.Untuk dosis $0,15 \mathrm{mg}$ ditimbang $1,5 \mathrm{~g}$ bubuk kopi kemudian dilarutkan dalam $100 \mathrm{~mL}$ akuades dan dipanaskan pada suhu $90^{\circ} \mathrm{C}$.

\section{Cara Pengambilan Data}

Penelitian ini merupakan penelitian eksperimental. Dilakukan pengelompokkan secara acak, 25 ekor tikus dibagi dalam 5 kelompok. Kelompok $\mathrm{K}_{1}$ merupakan kelompok tikus yang normal, kelompok $\mathrm{K}_{2}$ merupakan kelompok tikus hiperurisemia, yang tidak diberi perlakuan dengan kopi, kelompok $\mathrm{K}_{3}, \mathrm{~K}_{4}$ dan $\mathrm{K}_{5}$ merupakan kelompok tikus hiperurisemia yang diberi perlakuan dengan pemberian kopi dosis $0,5 \mathrm{mg} / \mathrm{g} \mathrm{BB}$, dosis $0,25 \mathrm{mg} / \mathrm{g}$ BB dan dosis $0,15 \mathrm{mg} / \mathrm{g}$ BB. Hewan diaklimatisasi selama satu minggu untuk beradaptasi dengan lingkungannya, setelah itu ditimbang untuk penentuan banyaknya kalium oksonat yang harus diberikan terhadap kelompok $\mathrm{K}_{2}, \mathrm{~K}_{3}, \mathrm{~K}_{4}$, dan $\mathrm{K}_{5}$ agar dapat diperoleh tikus hiperurisemia. Sebelum dilakukan penginduksian kalium oksonat, dilakukan pengambilan darah tikus untuk menghitung kadar MDA pada semua kelompok jam ke-0 (H0). Satu jam setelah induksi kalium, tikus perlakuan diberi cairan kopi sebanyak $2 \mathrm{~mL}$ melalui tuba nasogastrik (sonde). Pengukuran kadar MDA dilakukan kembali pada jam ke-6 (H6) dan jam ke-21 (H21) sesudah perlakuan pada kelompok $\mathrm{K}_{3}, \mathrm{~K}_{4}$, dan $\mathrm{K}_{5}$.

Pengukuran kadar MDA dilakukan dengan metode Thiobarbiturat Acid. Pengukuran dilakukan secara in duplo: hemolisat darah tikus sebanyak $250 \mu \mathrm{L}$ dimasukkan ke dalam microtube. Larutan TCA sebanyak $500 \mu \mathrm{L}$ ditambahkan kemudian diproses dengan centrifuge dengan kecepatan $1500 \mathrm{rpm}$ selama 5 menit. Setelah itu ditambahkan larutan TBA sebanyak $750 \mu \mathrm{L}$, kemudian dipanaskan pada suhu $100^{\circ} \mathrm{C}$ selama 10 menit. Setelah didinginkan, sampel dan blanko dipindahkan ke dalam kuvet untuk dianalisis menggunakan spektrofotometri pada panjang gelombang 532 $\mathrm{nm}$. Blanko yang digunakan berisi akuades 250 $\mu \mathrm{L}$, TCA sebanyak $500 \mu \mathrm{L}$ dan larutan TBA sebanyak $750 \mu \mathrm{L}$. Data absorban dari spekrofotometri dimasukan ke dalam persamaan regresi linear dari kurva standar TEP (Tetra Etoksi Propane) untuk menghitung kadar MDA sampel yang diperiksa. ${ }^{\mathbf{1 9 2 0}}$

\section{Kaji Etik}

Penelitian ini telah lolos kaji etik dari Komite Etik Penelitian FK Ukrida, No: 355/SLKE-IM/UKKW/FK/KE/XI/2017.

\section{Analisis Data}

Analisis data dilakukan dengan membandingkan kadar MDA pada tiga tahap pengambilan darah tikus yaitu kadar MDA awal pada jam ke-0 sebelum pemberian potassium oksonat, kadar MDA pada jam ke-6 dan ke-21 setelah pemberian kalium oksonat. Data berupa kadar MDA diuji secara deskriptif dan dianalisis menggunakan uji statistik One way Anova untuk mengetahui adanya perbedaan berupa penurunan kadar MDA setiap kelompok sebelum dan setelah perlakuan yaitu pada jam ke- 0 , jam ke-6 dan jam ke-21. Apabila terdapat perbedaan yang bermakna antara kelompok maka uji dilakukan dengan uji beda nyata terkecil (uji BNT). 


\section{Hasil dan Pembahasan}

Perhitungan kadar MDA didahului dengan pembuatan kurva standar TEP. Kurva standar TEP diperoleh dengan membuat plot absorbansi (serapan cahaya) larutan TEP dengan berbagai konsentrasi pada panjang gelombang $532 \mathrm{mn}$. Dengan kurva standar TEP tersebut dibuat persamaan regresi linearnya. Persamaan regresi linear tersebut kemudian digunakan untuk menghitung kadar MDA dalam darah setiap sampel (Gambar 1).

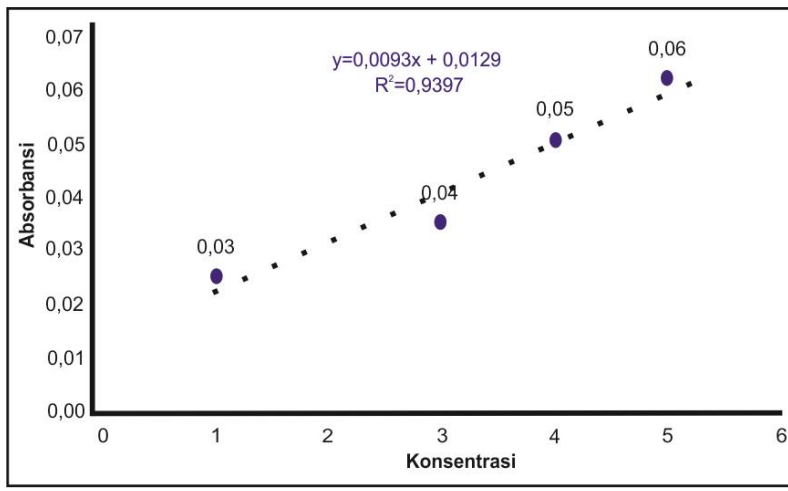

\section{Gambar 1. Kurva Standar TEP}

Kadar MDA tikus yang diperoleh dari hasil perhitungan sangat bervariasi di mana terjadi peningkatan dan penurunan baik pada tikus hiperurisemia yang diberikan perlakuan hanya dengan akuades, maupun tikus hiperurisemia yang diberikan perlakuan menggunakan ekstrak kopi. Tikus dikatakan hiperurisemia bila kadar asam urat di atas normal, dimana kadar asam urat normal pada tikus jantan strain winstar $1,11-4,3 \mathrm{mg} / \mathrm{dL}^{14}$ Dari hasil pengukuran kadar MDA data dianalisis dengan uji deskriptif yang dibuat dalam bentuk grafik (Gambar 2).

Data kadar MDA pada jam ke-0 (H-0) adalah data sebelum tikus disuntikkan kalium oksonat atau tikus yang sehat, belum mengalami hiperurisemia. Pada jam ke-0 (H-0) data kadar MDA rendah dibandingkan dengan data kadar MDA pada jam ke-6, yaitu data yang diperoleh enam jam setelah tikus disuntikkan kalium oksonat (H-6).

Pada kelompok tikus hiperurisemia yang diberi perlakuan dengan pemberian kopi arabika (kelompok tikus $\mathrm{K}_{2}, \mathrm{~K}_{3}, \mathrm{~K}_{4}$ ) terjadi peningkatan kadar MDA pada jam ke-6 (H-6) dan terjadi penurunan kadar MDA pada jam ke-21 (H-21). Terjadinya peningkatan kadar MDA pada jam ke-6 menunjukan senyawa kalium oksonat berpengaruh terhadap peningkatan kadar MDA, sedangkan penurunan kadar MDA pada kelompok tikus hiperurisemia yang diberi perlakuan pada jam ke-21 menunjukan bahwa pemberian infusa kopi mampu menurunkan kadar MDA tikus hiperurisemia.

Kalium oksonat diberikan dengan tujuan membuat tikus sehat menjadi hiperurisemia. ${ }^{15}$ Dalam keadaan hiperurisemia akan terjadi peningkatan radikal bebas, sehingga kadar MDA yang merupakan produk dari peroksidasi lipid akan meningkat. ${ }^{5}$ Pada jam ke-6, memperlihatkan kelompok tikus hiperurisemia yang tidak diberi perlakuan dengan kopi $\left(\mathrm{K}_{2}\right)$ terjadi peningkatan kadar MDA paling tinggi dibandingkan dengan kelompok tikus hiperurisemia dengan perlakuan pemberian kopi. Hal ini menunjukkan bahwa kopi yang diberikan pada tikus hiperurisemia tersebut memberikan efek dalam menurunkan kadar MDA, namun dari hasil uji statistik One way Anova diperoleh tidak adanya perbedaan kadar MDA yang signifikan antara kelompok $t$ ikus perlakuan pada jam ke-6, dengan $\mathrm{p}>0,05$ (Gambar 2).

Penelitian terdahulu menyatakan bahwa pada tikus hiperurisemia terjadi peningkatan enzim xantin oksidase, sehingga dapat menimbulkan peningkatan radikal bebas dalam tubuh. ${ }^{5}$ Radikal bebas dapat mengoksidasi lemak tubuh melalui peroksidasi membentuk MDA. ${ }^{5}$ Oleh karena itu seharusnya dalam penelitian ini, tikus yang diberi kalium oksonat akan terjadi hiperurisemia, sehingga MDA akan meningkat. ${ }^{5}$

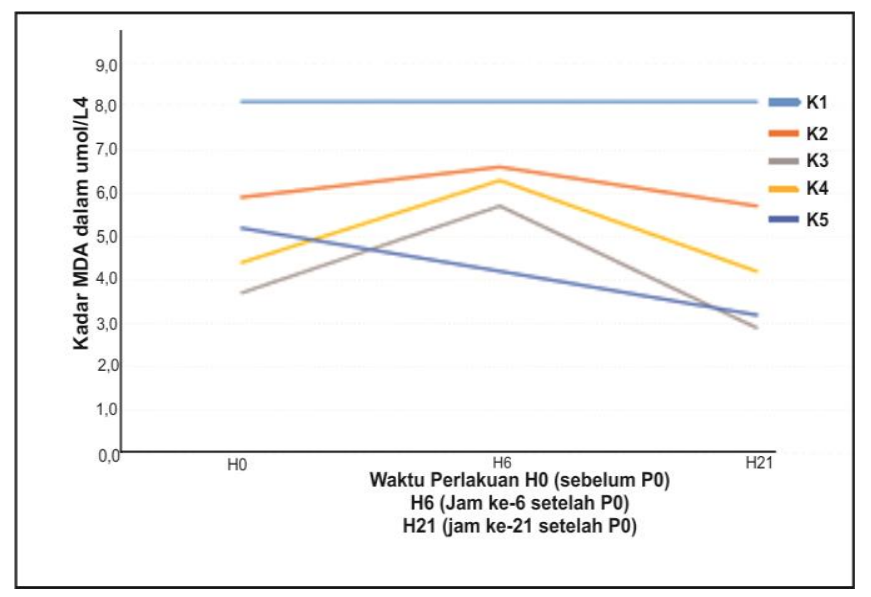

Gambar 2. Grafik Rata-Rata Kadar MDA: Kelompok Kontrol Negatif $\left(K_{1}\right)$, Kontrol Positif Tanpa Perlakuan $\left(\mathrm{K}_{2}\right)$, Kelompok Perlakuan dengan Pemberian Kopi Dosis 0,5 mg/200gBB $\left(K_{3}\right)$, Dosis 0,25 mg/200gBB $\left(K_{4}\right)$, dan Dosis 0,15 $\mathrm{mg} / 200 \mathrm{~g} B\left(\mathrm{~K}_{5}\right)$ pada Jam ke-0 (H-0), ke-6 (H-6), dan ke-21 (H-21) 
Hasil uji One Way Anova menunjukkan bahwa tidak ada perbedaan kadar MDA antara jam ke-0 dengan jam ke-6 dan ke-21 ( $p>0,05)$ antara kelompok kontrol negatif $\left(\mathrm{K}_{1}\right)$, kontrol positif $\left(\mathrm{K}_{2}\right)$, kelompok tikus dengan dosis 0,25 $\mathrm{mg} / 200 \mathrm{~g} \mathrm{BB}\left(\mathrm{K}_{4}\right)$, dan dosis $0,15 \mathrm{mg} / 200 \mathrm{~g} \mathrm{BB}$ $\left(\mathrm{K}_{5}\right)$. Sementara pada kelompok tikus hiperurisemia dengan pemberian kopi dosis 0,5 $\mathrm{mg} / 200 \mathrm{~g} \mathrm{BB}\left(\mathrm{K}_{3}\right)$ terdapat perbedaan kadar MDA antara jam ke- 0 dengan jam ke- 6 dan jam ke-21, dengan nilai $\mathrm{p}<0,05$ (Tabel 1). Ini menunjukkan bahwa pada kelompok tikus hiperurisemia yang diberi perlakuan dengan kopi dosis $0,5 \mathrm{mg} / 200 \mathrm{~g} \mathrm{BB}\left(\mathrm{K}_{3}\right)$ terjadi peningkatan kadar MDA yang signifikan pada jam ke-6 setelah induksi kalium oksonat, dibandingkan dengan kadar MDA pada jam ke-0. Tabel tersebut menunjukkan pula penurunan kadar MDA yang signifikan pada jam ke-21 jika dibandingkan dengan kadar MDA pada jam ke6. Pada jam ke -21, memperlihatkan bahwa kelompok tikus hiperurisemia yang diberi perlakuan pemberian kopi arabika dengan dosis $0,5 \mathrm{mg} / 200 \mathrm{~g} \mathrm{BB}$ memberikan efek penurunan kadar MDA paling besar dibandingkan dengan kelompok tikus lain. Hal ini diperkuat dengan hasil uji statistik BNT (post hoc), dapat dilihat pada Tabel 2, bahwa terdapat perbedaan kadar MDA yang signifikan antara kelompok tikus perlakuan pada jam ke-21, dengan $\mathrm{p}<0,05$.
Pada Tabel 3, hasil uji One Way Anova memperlihatkan bahwa data kadar MDA semua kelompok pada jam ke-21 ada perbedaan kadar MDA dengan nilai $\mathrm{p}<0,05$. Pada jam ke- 21 semua kelompok tikus hiperurisemia yang diberi perlakuan dengan kopi mengalami penurunan kadar MDA. Rata-rata kadar MDA kelompok tikus hiperurisemia yang diberikan kopi dosis 0,5 $\mathrm{mg} / 200 \mathrm{~g} \mathrm{BB}\left(\mathrm{K}_{3}\right)$ pada jam ke-21 paling rendah dibandingkan dengan kelompok perlakuan lainnya (Gambar 2), artinya pada kelompok tersebut terjadi penurunan kadar MDA terbesar dibandingkan kelompok yang lain.

Pemberian infusa kopi arabika pada penelitian ini telah mampu menurunkan kadar Malondialdehid (MDA) sampai batas normal. Kopi arabica dosis $0,5 \mathrm{mg} / 200 \mathrm{~g}$ BB merupakan dosis yang paling efektif dalam menurunkan kadar MDA darah tikus hiperurisemia pada penelitian ini. Dengan turunnya kadar MDA pada pemberian infusa kopi menunjukkan bahwa kopi memiliki aktivitas sebagai antioksidan.

Pada kondisi hiperurisemia (tingginya kadar asam urat) akibat pemberian kalium oksonat, terjadi aktivasi enzim xantin oksidase sehingga menimbulkan peningkatan radikal bebas dalam tubuh yang dapat menyebabkan kerusakan pada membran sel yang ditandai dengan peningkatan kadar MDA darah. ${ }^{18,21}$

Tabel 1. Hasil Uji Anova terhadap Tiap Kelompok pada H0, H6 dan H21

\begin{tabular}{|c|c|c|c|c|c|c|}
\hline & & Jumlah total kuadrat & Derajat Kebebasan & Rerata Kuadrat & $F$ & Sig \\
\hline & Antar Kelompok & 0,000 & 2 & 0,000 & 0,000 & 1,000 \\
\hline & Dalam Kelompok & 6141,600 & 12 & 511,800 & & \\
\hline \multirow[t]{2}{*}{$\mathbf{K}_{1}$} & Total & 6141,600 & 14 & & & \\
\hline & Antar Kelompok & 209,200 & 2 & 104,600 & 3,772 & $\mathbf{0 , 0 5 4}$ \\
\hline \multirow[t]{3}{*}{$\mathbf{K}_{2}$} & Dalam Kelompok & 332,800 & 12 & 27,733 & & \\
\hline & Total & 542,000 & 14 & & & \\
\hline & Antar Kelompok & 2310,933 & 2 & 1155,467 & 6,534 & $\mathbf{0 , 0 1 2}$ \\
\hline \multirow[t]{3}{*}{$\mathbf{K}_{3}$} & Dalam Kelompok & 2122,000 & 12 & 176,833 & & \\
\hline & Total & 4432,933 & 14 & & & \\
\hline & Antar Kelompok & 1332,133 & 2 & 666,067 & 0,688 & $\mathbf{0 , 5 2 1}$ \\
\hline \multirow[t]{3}{*}{$\mathbf{K}_{4}$} & Dalam Kelompok & 11616,800 & 12 & 968,06 & & \\
\hline & Total & 12948,933 & 14 & & & \\
\hline & Antar Kelompok & 1040,533 & 2 & 520,267 & 1,260 & $\mathbf{0 , 3 1 9}$ \\
\hline \multirow[t]{2}{*}{$\mathbf{K}_{5}$} & Dalam Kelompok & 4956,800 & 12 & 413,067 & & \\
\hline & Total & 5997,333 & 14 & & & \\
\hline
\end{tabular}


Tabel 2. Hasil Uji Post Hoc (LSD)

\begin{tabular}{|c|c|c|c|c|c|c|c|}
\hline \multirow[b]{2}{*}{$\begin{array}{l}\text { Variabel } \\
\text { terikat }\end{array}$} & \multirow[b]{2}{*}{ (I) Kelompok } & \multirow{2}{*}{$\begin{array}{c}(\mathbf{J}) \\
\underset{\mathbf{k}}{\text { Kelompo }}\end{array}$} & \multirow[b]{2}{*}{$\begin{array}{l}\text { Beda Rata- } \\
\text { Rata (I-J) }\end{array}$} & \multirow[b]{2}{*}{$\begin{array}{l}\text { Std. } \\
\text { Error }\end{array}$} & \multirow[b]{2}{*}{ Sig. } & \multicolumn{2}{|c|}{$\begin{array}{l}\text { 95\% Interval } \\
\text { Kepercayaan }\end{array}$} \\
\hline & & & & & & $\begin{array}{l}\text { Batas } \\
\text { Bawah }\end{array}$ & Batas Atas \\
\hline \multirow[t]{20}{*}{$\mathrm{H} 21$} & 1 & 2 & $23,74200^{*}$ & 9,40167 & 0,020 & 4,1305 & 43,3535 \\
\hline & & 3 & $52,34400^{*}$ & 9,40167 & 0,000 & 32,7325 & 71,9555 \\
\hline & & 4 & $61 ., 6000^{*}$ & 9,40167 & 0,000 & 41,5485 & 80,7715 \\
\hline & & 5 & $49,11600^{*}$ & 9,40167 & 0,000 & 29,5045 & 68,7275 \\
\hline & 2 & 1 & $-23,74200^{*}$ & 9,40167 & 0,020 & $-43,3535$ & $-4,1305$ \\
\hline & & 3 & $28,60200^{*}$ & 9,40167 & 0,006 & 8,9905 & 48,2135 \\
\hline & & 4 & $37,41800^{*}$ & 9,40167 & 0,001 & 17,8065 & 57,0295 \\
\hline & & 5 & $25.37400^{*}$ & 9,40167 & 0,014 & 5,7625 & 44,9855 \\
\hline & 3 & 1 & $-52,34400^{*}$ & 9,40167 & 0,000 & $-71,9555$ & $-32,7325$ \\
\hline & & 2 & $-28,60200^{*}$ & 9,40167 & 0,006 & $-48,2135$ & $-8,9905$ \\
\hline & & 4 & 8,81600 & 9,40167 & 0,360 & $-10,7955$ & 28,4275 \\
\hline & & 5 & $-3,22800$ & 9,40167 & 0,735 & $-22,8395$ & 16,835 \\
\hline & 4 & 1 & $-61,16000^{*}$ & 9,40167 & 0,000 & $-80,7715$ & $-41,5485$ \\
\hline & & 2 & $-37,41800^{*}$ & 9,40167 & 0,001 & $-57,0295$ & $-17,8065$ \\
\hline & & 3 & $-8,81600$ & 9,40167 & 0,360 & $-28,4275$ & 10,7955 \\
\hline & & 5 & $-12,04400$ & 9,40167 & 0,215 & $-31,6555$ & 7,5675 \\
\hline & 5 & 1 & $-49,11600^{*}$ & 9,40167 & 0,000 & $-68,7275$ & $-29,5045$ \\
\hline & $\begin{array}{l}\text { *Perbedaan rerata } \\
\text { signifikan pada taraf }\end{array}$ & 2 & $-25,37400^{*}$ & 9,40167 & 0,014 & $-44,9855$ & $-5,7625$ \\
\hline & 0,05 & 3 & 3,22800 & 9,40167 & 0,735 & $-16,3835$ & 22,8395 \\
\hline & & 4 & 12,04400 & 9,40167 & 0,215 & $-7,5675$ & 31,6555 \\
\hline
\end{tabular}

Tabel 3. Hasil Uji ANOVA terhadap Semua Kelompok pada H0, H6, H21

\begin{tabular}{|c|c|c|c|c|c|c|}
\hline & & $\begin{array}{l}\text { Jumlah } \\
\text { Kuadrat }\end{array}$ & $\begin{array}{c}\text { Derajat } \\
\text { Kebebasan }\end{array}$ & Rata-Rata & $F$ & Sig. \\
\hline \multirow[t]{3}{*}{ HO } & Antar Kelompok & 5466,339 & 4 & 1366,585 & 3,752 & $\mathbf{0 , 0 2 0}$ \\
\hline & Dalam Kelompok & 7283,869 & 20 & 364,193 & & \\
\hline & Total & 12750,208 & 24 & & & \\
\hline \multirow[t]{3}{*}{ H6 } & Antar Kelompok & 3923,254 & 4 & 980,814 & 1,633 & 0,205 \\
\hline & Dalam Kelompok & 12013,865 & 20 & 600,693 & & \\
\hline & Total & 15937,119 & 24 & & & \\
\hline \multirow[t]{3}{*}{ H21 } & Antar Kelompok & 11833,507 & 4 & 2958,377 & 11,537 & 0,000 \\
\hline & Dalam Kelompok & 5128,299 & 20 & 256,415 & & \\
\hline & Total & 16961,806 & 24 & & & \\
\hline
\end{tabular}

Kopi arabika mengandung senyawa polifenol yang didalamnya terdapat Chlorogenic acid. Senyawa ini memiliki efek menghambat enzim xanthin oxidase sehingga menurunkan kadar asam urat. Selain itu senyawa polifenol juga memiliki efek diuretik yang dapat mempercepat ekskresi asam urat dalam urin sehingga menurunkan kadar asam urat. ${ }^{15,22}$ Kadar asam urat yang tinggi seperti pada penderita hiperurisemia dapat menyebabkan kerusakan pada membran sel yang ditandai dengan peningkatan kadar malondialdehida. Peningkatan kadar MDA merupakan parameter oksidan di dalam tubuh, maka dengan pemberian antioksidan berupa infusa kopi arabika dapat terjadi penurunan kadar MDA yang terdapat di dalam darah. ${ }^{13,14,16 \text {, }}$ 


\section{Simpulan}

Pemberian kalium oksonat menyebabkan kondisi hiperurisemia, di mana pada kondisi tersebut, akan terjadi peningkatan radikal bebas yang akan merusak membran sel, ditandai dengan terjadinya peningkatan kadar MDA dalam darah.

Pemberian infusa kopi arabika memberikan efek penurunan kadar MDA darah yang signifikan pada jam ke-21 dan infusa kopi arabika yang efektif dalam menurunkan kadar MDA darah adalah dengan dosis $0,5 \mathrm{mg} / 200 \mathrm{~g} \mathrm{BB}$.

Penurunan kadar MDA pada kondisi hiperurisemia pada penelitian ini, membuktikan bahwa infusa kopi arabika memiliki aktivitas sebagai antioksidan. Senyawa polifenol, yaitu chlorogenic acid, yang terkandung dalam infusa kopi, akan menghambat aktivitas enzim xanthin oksidase sehingga menurunkan kadar asam urat, dan akhirnya dapat menurunkan efek radikal bebas terhadap kerusakan membran sel, yang ditandai dengan turunnya kadar MDA darah.

\section{Daftar Pustaka}

1. Carter MA. Gout dalam patofosiologi: Konsep klinis. Proses-proses penyakit. Jakarta: EGC; 2006. pp. 1402-1405.

2. Soeroso J, Algristian H. Asam urat. Jakarta: Penerbit Penebar Plus; 2011.

3. Mark VB, Evert GS, Martin BK. Coffee bean extract rich and poor in kahweol both rise to elevation of liver enzyms in healthy volunteers. Nutrition Journal. Netherlands: Wageningen University; 2004.

4. Meguro S, Hasumura T, Hase T. Coffee polyphenols exert hypocholesterolemic effects in zebrafish fed a highcholesterol diet. Nutr Metab. 2013. (diunduh 19 Maret 2017). Tersedia dari: URL: HYPERLINK http://www.ncbi.nlm.nih.gov/pmc/articl es/PMC3871761/.

5. Underwood JCE. Gangguan metabolisme dan keseimbangan,
Dalam: Patologi umum dan sistemik. Edisi ke-2. Jakarta: Penerbit EGC; 2000; hal. 150-2.

6. Kelly WN, Wortmann RL. Crystalassociated synovitis: gout and hyperuricemia. 5th ed. Philadelphia: WB Saunders; 1997. hlm. 47- 131.

7. Kanbara A, Hakoda M, Seyama I. Urine alkalization facilitates uric acid excretion. Nutritional Journal, 2010; 9: 45.

8. Cook NC, Samman S. Flavanoid, chemistry, metabolism, cardioprotective effects, and dietary source. Journal Nutritional Biochemistry. 2006;7:66-76.

9. Murray RK, Bender DA, Botman KM, Kennelly PJ, Rodwell VW, Weil PA. Biokimia harper. Edisi 29. Jakarta: Penerbit EGC; 2014.

10. Wijayakusuma H. Tumbuhan berkhasiat obat indonesia rempah, rimpang dan umbi. Jakarta: Prestasi Instan Indonesia; 2002.

11. Ariyanti R. Pengaruh pemberian infusa daun salam (Eugenia polyantha wight) terhadap penurunan kadar asam urat darah mencit putih jantan yang diinduksi dengan potassium oksonat. Skripsi.Surakarta: Fakultas Farmasi Universitas Muhammadiyah Surakarta; 2007.

12. Hamzah L, Arifin H, Ahmad A. Pengaruh ekstrak etanol rambut jagung (Zea mays L.) terhadap kadar asam urat darah mencit putih jantan hiperurisemia. Prosiding Seminar Nasional dan Workshop "Perkembangan Terkini Sains Farmasi dan Klinik IV"; 2014.

13. Ayelign A, Sabally K. Determination of chlorogenic acids (cga) in coffee beans using HPLC. Department of Post Harvest Management College of Agriculture and Veterinary Medicine Jimma University, Ethiopia; 2013.p.34.

14. Farhaty N, Muchtaridi. Tinjauan kimia dan aspek farmakologi senyawa asam klorogenat pada biji kopi. Jurnal Farmaka Fakultas Farmasi Universitas Padjadjaran, 2014; 4(1). 
15. Koto FA, Kadri H, Rofinda ẐD. Pengaruh pemberian kopi instan oral terhadap kadar asam urat pada tikus wistar. Jurnal Kesehatan Andalas, 2014; 3(3).

16. Lelyana R. Pengaruh kopi terhadap kadar asam urat darah. Tesis. Semarang: Program Pascasarjana Magister Ilmu Biomedik Universitas Diponegoro; 2008.

17. Kiyohara C, Kono S, Honjo S, Todoroki I, Sakurai Y, Nishiwaki M, et al. Inverse association between coffee drinking and serum uric acid concentrations in middleaged Japanese males. Br J Nutr. 1999 (diunduh 09 April 2017). Tersedia dari: URL: hyperlink http://www.ncbi.nlm.nih. gov/pubmed/10743484.

18. Kanbara A, Hakoda M, Seyama I. Urine alkalization facilitates uric acid excretion. Nutritional Journal, 2010; 9: 45.

19. Rahayu N, Mushawwir A, Latipudin D. Profil malondialdehid dan kolesterol darah ayam petelur fase layer pada temperature humidity index yang berbeda. Bandung: Fakultas Peternakan, Universitas Padjadjaran; Students e-Journals 2015;4(1)

20. Soewoto H, Sadikin M, Kurniati V, Wanandi SI, Retno D, Abadi P, Prijanti AP, Harahap IP, Jusman SWA. Biokimia: eksperimen laboratorium. Jakarta: Widya Medika; 2001.

21. Ariyanti R, Wahyuningtyas N, Wahyuni AS. Pengaruh pemberian infusa daun salam (Eugenia polyantha Wight) terhadap penurunan kadar asam urat darah mencit putih jantan yang diinduksi dengan potasium oksonat. Pharmacon, 2007;8(2):56-63 